\title{
Extracorporeal cell therapy of septic shock patients with donor granulocytes: a pilot study
}

\author{
Jens Altrichter ${ }^{1}$, Martin Sauer ${ }^{2}$, Katharina Kaftan', Thomas Birken², Doris Gloger ${ }^{3}$, Martin Gloger ${ }^{4}$, Jörg Henschel', \\ Heiko Hickstein ${ }^{1}$, Ernst Klarr, Sebastian Koball', Annette Pertschy ${ }^{5}$, Gabriele Nöldge-Schomburg ${ }^{2}$, \\ Dierk A Vagts ${ }^{2}$ and Steffen R Mitzner ${ }^{1 *}$
}

\begin{abstract}
Introduction: Neutrophil granulocytes are the first defense line in bacterial infections. However, granulocytes are also responsible for severe local tissue impairment. In order to use donor granulocytes, but at the same time to avoid local side effects, we developed an extracorporeal immune support system. This first-in-man study investigated whether an extracorporeal plasma treatment with a granulocyte bioreactor is tolerable in patients with septic shock. A further intention was to find suitable efficacy end-points for subsequent controlled trials.

Methods: The trial was conducted as a prospective uncontrolled clinical phase I/II study with 28-day follow-up at three university hospital intensive care units. Ten consecutive patients (five men, five women, mean age $60.3 \pm$ 13.9 standard deviation (SD) years) with septic shock with mean ICU entrance scores of Acute Physiology and Chronic Health Evaluation (APACHE) II of $29.9 \pm 7.2$ and of Simplified Acute Physiology Score (SAPS) II of $66.2 \pm$ 19.5 were treated twice within 72 hours for a mean of $342 \pm 64$ minutes/treatment with an extracorporeal bioreactor containing $1.41 \pm 0.43 \times 10$ E10 granulocytes from healthy donors. On average, $9.8 \pm 2.3$ liters separated plasma were treated by the therapeutic donor cells. Patients were followed up for 28 days.

Results: Tolerance and technical safety during treatment, single organ functions pre/post treatment, and hospital survival were monitored. The extracorporeal treatments were well tolerated. During the treatments, the bacterial endotoxin concentration showed significant reduction. Furthermore, noradrenaline dosage could be significantly reduced while mean arterial pressure was stable. Also, C-reactive protein, procalcitonin, and human leukocyte antigen DR (HLA-DR) showed significant improvement. Four patients died in the hospital on days 6, 9, 18 and 40. Six patients could be discharged.
\end{abstract}

Conclusions: The extracorporeal treatment with donor granulocytes appeared to be well tolerated and showed promising efficacy results, encouraging further studies.

Trial registration: ClinicalTrials.gov Identifier: NCT00818597

\section{Introduction}

Despite tremendous advances in critical care medicine, sepsis is still a leading cause of morbidity and mortality in non-coronary ICUs. In the USA, approximately 215,000 patients die each year as a consequence of sepsis [1]. The often unsuccessful efforts to rescue septic patients in ICU are extremely expensive and costs are approaching US \$17 billion annually in the United States [1].

\footnotetext{
* Correspondence: steffen.mitzner@med.uni-rostock.de

'Department of Medicine, Division of Nephrology, Medical Faculty of the University of Rostock, Ernst-Heydemann-Str. 6, Rostock, D-18057, Germany Full list of author information is available at the end of the article
}

The underlying deregulated immune mechanisms that lead to the development of sepsis are highly complex and involve both overshooting inflammatory responses of the innate immune system and the lack of adequate anti-microbial immune responses both by the innate and adaptive arm of immunity. In particular, neutrophils, the prototype of non-specific early anti-microbial effector cells, may lead to collateral damages such as disruption of endothelial integrity and impairment of microcirculation within organs, for example, by overproduction of proteases and oxygen radicals [2-4]. On the other hand, the physiological effector functions of

\section{Biomed Central}


neutrophils are believed to be essential to control the microbial load. Moreover, functional impairment of neutrophils and other immune cells has been shown to be associated with increased mortality in advanced stages of sepsis and septic shock [5-7].

In the past, efforts to stimulate the innate immune system with granulocyte-colony stimulating factor (GCSF), granulocyte-macrophage-colony stimulating factor (GM-CSF) or interferon gamma (IFN-gamma) in septic patients failed to decrease mortality rates in septic patients. However, except for neonates, no sufficiently powered studies were performed in this field [8-10]. Likewise, the transfusion of granulocyte preparations (GTx) failed to improve survival in sepsis and neutropenia $[11,12]$. Nevertheless, there is some indication that steroid- or G-CSF-stimulated high-yield granulocytedonations might result in better survival in severe infections associated with neutropenia and cancer [12,13].

In order to deploy the beneficial features of neutrophils such as phagocytosis of cellular debris, antigenic material or pathogens, and at the same time to circumvent the possible damaging local effects of systemically transfused neutrophils, a bed-side bioreactor was developed, that uses granulocytes in a strictly extracorporeal mode. This bioreactor consists of a plasma separating device and an extracorporeal circuit containing donor neutrophils. The patient is connected to the extracorporeal circuit for the whole treatment. Plasma from septic patients is perfused through the neutrophil housing and the treated plasma is re-infused online into the patient. The bioreactor-cells are retained in the extracorporeal system and discarded after the treatment.

In in vitro studies [14] and in a large animal model for Gram-positive sepsis [15], we were able to show the proof of principle and promising survival data. Therefore, the bioreactor is now being studied in patients with septic shock in order to show tolerability and feasibility of this kind of complex therapy. Furthermore, this pilot trial should give hints for relevant end points to adequately power a subsequent controlled study. This is the first report showing data from a pilot study on ICU on the efficacy and tolerability of a granulocyte bioreactor system.

\section{Materials and methods}

The study was conducted in accordance with the Helsinki Declaration, received ethics approval from the local research ethics committee, and the state authorities were notified according to German pharmaceutical and medical device law. The trial has been registered at ClinicalTrials.gov under reg.-no: NCT00818597. Written informed consent was obtained from all participants or from the patients' representatives if direct consent could not be obtained.

\section{Patients}

During a four-month period all patients of one medical and two surgical intensive care units of a tertiary care university hospital were screened to see if they fulfilled the parameters of severe sepsis and septic shock as defined by international consensus criteria [16]. Definitions of organ dysfunctions were adopted from the "Recombinant Human Activated Protein C Worldwide Evaluation In Severe Sepsis Study" (PROWESS Study) [17] with the difference being that liver failure was not an exclusion criterion in this current study. The exclusion criteria were age under 18 years, hepatitis $C$, active bleeding and HIV infection. Ten consecutive patients with septic shock were enrolled in the study.

\section{Procedures}

The study flow is depicted in Figure 1. After inclusion of a patient, a healthy blood donor was identified and stimulated with corticosteroids (each $20 \mathrm{mg}$ p.o. methylprednisolone, Sanofi-Aventis Deutschland $\mathrm{GmbH}$, Frankfurt, Germany) $17 \mathrm{~h}, 12 \mathrm{~h}$ and $2 \mathrm{~h}$ before donation of an ABO-compatible granulocyte concentrate. Granulocytes were collected by extracorporeal density gradient centrifugation using hydroxyethylstarch (HES 200/0.5 6\%, Fresenius Kabi AG, Bad Homburg, Germany) and citrate in a cell separator (COBE Spectra, Gambro BCT, Planegg-Martinsried, Germany) according to standard procedures. Because of the delay due to identification and stimulation of a compatible donor the first treatment of a patient was one day after inclusion in four cases, two days after inclusion in three cases, and three days after inclusion in two cases. Prior to treatment the inclusion criteria were re-confirmed. The whole extracorporeal system was first rinsed and prefilled with hemofiltration solution HF-BIC 35-410 with $4 \mathrm{mM}$ potassium (Fresenius Medical Care, Bad Homburg, Germany). In mean $1.41 \pm 0.43 \times 10 \mathrm{E} 10$ donor granulocytes were delivered in donor plasma and were placed into the bioreactor compartment of the device prior to connection to the patient. An excess of hemofiltration solution during cell filling was discarded; therefore, no additional fluid was infused into the patient. The patients were treated for up to six hours with an extracorporeal method consisting of a plasma separation and plasma perfusion through the cell-compartment containing the donor cells. Blood access was veno-venous via a Shaldon-catheter. Plasma separation was carried out by a dialysis monitor (BM25, Edwards Lifesciences $\mathrm{GmbH}$, Unterschleissheim, Germany) using a $0.5 \mu \mathrm{m}$ pore-size plasma filter (PF 1000N, Gambro Hospal GmbH, Planegg-Martinsried, Germany). The plasma was infused into the continuously re-circulating donor cell compartment. A schematic view of the extracorporeal treatment device is shown in Figure 2. Plasma reflux to the patient 


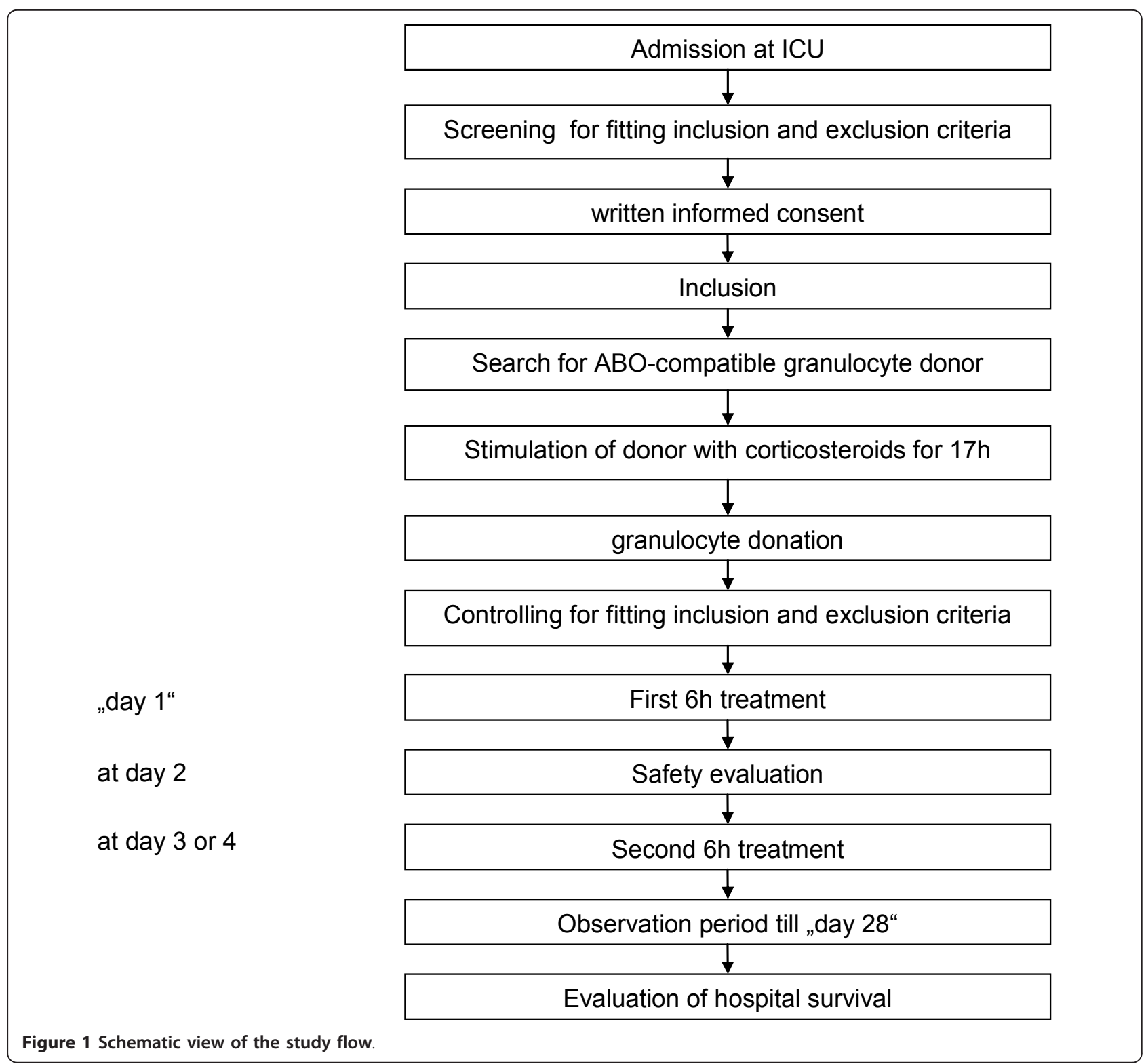

was done through a second PF $1000 \mathrm{~N}$ plasma filter to withhold the donor cells from being infused into the patient. Total extracorporeal volume was $400 \mathrm{ml}$. The blood flow rate was 150 to $200 \mathrm{ml} /$ minute with a plasma separation rate of 16.7 to $33.3 \mathrm{ml}$ plasma/minute using the BM 25 monitor. The MARS-Monitor 1 TC (Gambro Rostock GmbH, Rostock, Germany) was used for the recirculating bioreactor circuit at a rate of $200 \mathrm{ml} /$ minute and to maintain the temperature in the cell compartment at $37^{\circ} \mathrm{C}$. Unfractionated heparin $(20 \mathrm{IU} / \mathrm{kg}$, Roche, Grenzach-Wyhlen, Germany) was given at the beginning of the extracorporeal treatment followed by a continuous infusion into the circuit. Heparin administration was adjusted to maintain activated clotting time (ACT) between 150 to 200 seconds. Following tolerability assessment of the first treatment, all patients were treated a second time 48 to 72 hours after the first treatment, again for up to 6 hours with granulocytes from the same donor.

\section{Measurements}

We recorded basic demographic information, illness severity (Acute Physiology and Chronic Health Evaluation (APACHE) II, Sequential Organ Failure Assessment (SOFA), Multiple Organ Dysfunction Score (MODS), and Simplified Acute Physiology Score (SAPS) II scores), microbiological results, pre-morbidity, and clinical outcome for the study cohort (see Table 1). Patients were followed up for 28 days and hospital survival. At the days "inclusion", 1 to $8,10,12,14,21,28$ and before/ after an extracorporeal bioreactor-treatment the patients 


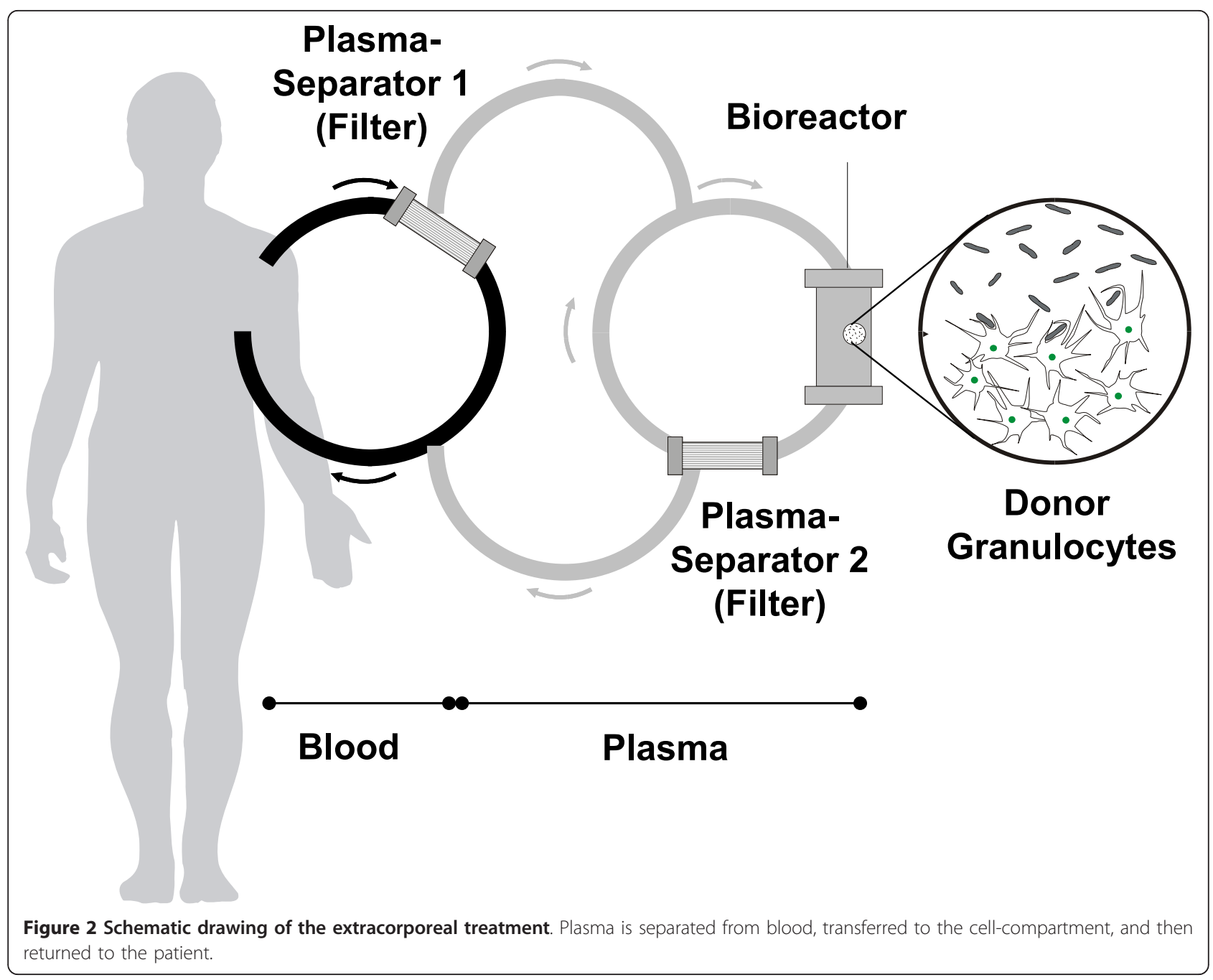

were screened for clinical and immunological data: hemodynamic, inflammation, coagulation, hemolysis, temperature, organ function blood parameters, endotoxin, cytokines, complement $(\mathrm{C} 3, \mathrm{C} 4)$, and the number of human leukocyte antigen DR (HLA-DR) molecules per monocyte surface. "Day 1" was defined as the day of the first bioreactor treatment. Viability and functionality of the donor cells were tested at the begin and end of the treatments by trypan blue test, phagocytosis by flow cytometry (Beckman Coulter Immunotech, Krefeld, Germany) with florescence-labeled E. coli and oxyburst both by flow cytometry with dihydrorhodamine 123 as well as in a luminometer (Thermo Labsystems, Waltham, MA, USA) with luminol and lucigenin.

\section{Statistical analysis}

The Statistical Package for the Social Sciences (SPSS, IBM Corporation, Somer, NY, USA) was used to conduct nonparametric analyses using the Friedman-test and Wilcoxon-test. In addition to the evaluation of the raw data, a Last Observation Carried Forward (LOCF) analysis was performed to limit the bias due to the dropout of the three non-survivors during the 28 days observation period. The results are expressed as the mean \pm standard deviation (SD). Differences were considered significant at $P<0.05$.

\section{Results}

\section{Patients}

Ten consecutive patients with septic shock were included in the study. Details concerning diagnoses, age, sex, relevant scores and survival are shown in Table 1. All patients had positive microbial tests with a mean of $4.7 \pm 2.6$ different microbial species per patient, predominantly candida, coagulase negative staphylococcus, enterococcus and E. coli.

Observations during the treatments: technical results During the first treatment performed in this study the heparin use was adjusted to a target ACT of 125 to $150 \mathrm{sec}$. 
Table 1 Patients characteristics, illness severity, premorbidity and clinical outcome for study cohort $(n=10)$

\begin{tabular}{|c|c|c|c|c|c|c|c|c|}
\hline Patient & $\begin{array}{l}\text { Major diagnoses } \\
\text { at inclusion }\end{array}$ & Premorbidity & $\begin{array}{c}\text { APACHE } \\
\text { II at ICU } \\
\text { arrival }\end{array}$ & $\begin{array}{l}\text { SOFA at ICU } \\
\text { arrival/at } \\
\text { inclusion }\end{array}$ & $\begin{array}{l}\text { SAPS II at } \\
\text { ICU arrival/ } \\
\text { at inclusion }\end{array}$ & $\begin{array}{l}\text { Hospital } \\
\text { survival }\end{array}$ & $\begin{array}{l}\text { Inclusion } \\
\text { at ICU } \\
\text { day }\end{array}$ & $\begin{array}{l}\text { Time between } \\
\text { inclusion and first } \\
\text { treatment in days }\end{array}$ \\
\hline 1 & Pneumonia, ALI, SS & Alcohol abuse & 37 & $15 / 16$ & $96 / 80$ & Survived & 1 & 2 \\
\hline 2 & $\begin{array}{c}\text { Necrotizing } \\
\text { pancreatitis, } \\
\text { Pneumonia, SS }\end{array}$ & Alcohol abuse & 27 & $12 / 11$ & $61 / 61$ & Survived & 9 & 1 \\
\hline 3 & $\begin{array}{l}\text { Pneumonia, ALI, } \\
\text { Urogenital } \\
\text { infection, SS }\end{array}$ & $\begin{array}{l}\text { Ischemic heart disease, } \\
\text { Hydrocephalus, brain-tumor } \\
\text { operation }\end{array}$ & 30 & $12 / 11$ & $66 / 58$ & $\begin{array}{l}\text { Died } \\
\text { (Day 18) }\end{array}$ & 3 & 1 \\
\hline 4 & ALI, SS, Liver failure & $\begin{array}{l}\text { Liver cirrhosis, COPD, } \\
\text { Diabetes mellitus }\end{array}$ & 37 & $17 / 17$ & $72 / 73$ & $\begin{array}{l}\text { Died } \\
\text { (Day 9) }\end{array}$ & 10 & 1 \\
\hline 5 & $\begin{array}{l}\text { Cardiopulmonary } \\
\text { resuscitation, ALI, } \\
\text { SS }\end{array}$ & $\begin{array}{c}\text { Alcohol abuse, } \\
\text { Encephalopathy, Ischemic } \\
\text { heart disease }\end{array}$ & 36 & $11 / 13$ & $83 / 66$ & Survived & 4 & 1 \\
\hline 6 & Mediastinitis, SS & Alcohol abuse & 27 & $14 / 13$ & $70 / 63$ & Survived & 1 & 2 \\
\hline 7 & $\begin{array}{l}\text { Hip joint } \\
\text { endoprosthesis } \\
\text { infection, SS }\end{array}$ & Diabetes mellitus & 21 & $8 / 6$ & $35 / 35$ & $\begin{array}{l}\text { Died } \\
\text { (Day 40) }\end{array}$ & 1 & 3 \\
\hline 8 & $\begin{array}{l}\text { Postoperative } \\
\text { shock after ACB- } \\
\text { surgery, ARF, SS }\end{array}$ & $\begin{array}{l}\text { Ischemic heart disease, } \\
\text { Cardiac failure }\end{array}$ & 38 & $13 / 9$ & $74 / 50$ & Survived & 6 & 12 \\
\hline 9 & $\begin{array}{l}\text { Renal failure, } \\
\text { Kidney infection, } \\
\text { SS }\end{array}$ & Polycystic Kidney and Liver & 29 & $8 / 12$ & $72 / 31$ & Survived & 3 & 2 \\
\hline 10 & $\begin{array}{l}\text { Thoracic infection } \\
\text { after sternum } \\
\text { resection, ARF, SS }\end{array}$ & $\begin{array}{l}\text { Radio-Necrosis of Sternum } \\
\text { after Radio-Chemotherapy } \\
\text { due to Breast Cancer }\end{array}$ & 17 & $8 / 11$ & $33 / 70$ & $\begin{array}{l}\text { Died } \\
\text { (Day 6) }\end{array}$ & 27 & 3 \\
\hline Median & & & 29 & $12 / 11$ & $70 / 61$ & & 4 & 2 \\
\hline Mean & & & 29.9 & $11.8 / 11.9$ & $66.2 / 58.7$ & & 6.5 & 2.8 \\
\hline
\end{tabular}

$\mathrm{ACB}$, aortocoronary bypass, ALI, acute lung injury, ARF, acute renal failure, COPD, chronic obstructive pulmonary disease, SS, septic shock.

After about 90 minutes the cell filter clotted and the treatment had to be terminated. Therefore, in all further treatments the heparin dosage was adjusted according to a target ACT of 150 to 200 sec. Except for Patient 6 where treatment \#2 had to be terminated after five hours due to increased transmembranal pressure across the cell filter, all other treatments were carried out for six hours. Mean treatment time was $342 \pm 64$ minutes. Blood flow varied from 150 to $200 \mathrm{ml} /$ minute depending on the patient's quality of blood access. The flow rate in the cell therapy circuit was $200 \mathrm{ml} /$ minute. Plasma flow started with $16.7 \mathrm{ml} /$ minute for the first 15 to 30 minutes and then increased to $33.3 \mathrm{ml} /$ minute. A mean of $9.8 \pm 2.5$ liters of plasma were treated during each of the 20 treatments. To test whether the donor cells were still functional every two hours, cells from the cell circuit were evaluated for viability and functionality. For the whole treatment the cells showed a viability of more than $90 \%$ and unimpaired cellular functions like phagocytosis and oxidative burst.

\section{Primary endpoints (safety): hemodynamic}

During the extracorporeal procedures, no significant drop in mean arterial pressure was observed. All patients were on noradrenaline at the beginning of the first treatment and five of these patients also received it at the start of the second treatment. In 10 of the 20 procedures the noradrenaline dose could be reduced due to an increase in the mean arterial pressure. In five treatments the noradrenaline dose remained unchanged. Only in one case (Patient 4, second treatment) the noradrenaline infusion that had been turned off before the treatment was turned on again during the treatment, however, at a small dose $(0.03 \mu \mathrm{g} / \mathrm{kg} /$ minute $)$. Overall the Wilcoxon test showed a significant reduction in the noradrenaline dose (median from 0.06 to $0.035 \mu \mathrm{g} / \mathrm{kg} /$ minute; $P=0.016$; Table 2) while the mean arterial pressure was stable during the bioreactor-treatment (median before 74, after $80 \mathrm{mmHg}$; not significant). Systemic vascular resistance index (SVRI) was not monitored in this study.

\section{Coagulation disorders}

There was no significant change in mean platelet counts during the extracorporeal treatment (Table 2). D-dimers did increase significantly during the extracorporeal treatment from $752 \pm 505 \mu \mathrm{g} / \mathrm{l}$ to $853 \pm 450 \mu \mathrm{g} / \mathrm{l}$ but returned to $609 \pm 381 \mu / \mathrm{l}$ within 12 hours. Antithrombin III concentration also changed significantly from 66 
Table 2 Main laboratory parameters before and after the extracorporeal treatments

\begin{tabular}{|c|c|c|c|c|}
\hline Parameter & Unit & Before extracorporeal treatment $n=20$ & After $6 \mathrm{~h}$ extracorporeal treatment $n=20$ & $P$-value \\
\hline \multicolumn{5}{|l|}{ Inflammation } \\
\hline Leukocytes & Gpt/l & $12.2 \pm 6.6$ & $20.8 \pm 12.4$ & $P<0.01$ \\
\hline Banded neutrophils & $\%$ & $73 \pm 11$ & $70 \pm 10$ & n.s. \\
\hline Segmented neutrophils & $\%$ & $18 \pm 11$ & $18 \pm 12$ & n.s. \\
\hline C-reactive protein & $\mathrm{mg} / \mathrm{l}$ & $190 \pm 130$ & $165 \pm 119$ & $P<0.01$ \\
\hline Procalcitonin & $\mathrm{ng} / \mathrm{l}$ & $10.1 \pm 23.4$ & $6.8 \pm 14.6$ & $P<0.01$ \\
\hline Endotoxin & $\mathrm{pg} / \mathrm{ml}$ & $16.4 \pm 7.7$ & $13.5 \pm 5.5$ & $P<0.05$ \\
\hline Temperature & ${ }^{\circ} \mathrm{C}$ & $36.86 \pm 0.97$ & $36.73 \pm 0.87$ & n.s. \\
\hline \multicolumn{5}{|l|}{ Hemodynamic } \\
\hline Noradrenaline & $\mu \mathrm{g} / \mathrm{kg} / \mathrm{minute}$ & $0.10 \pm 0.12$ & $0.08 \pm 0.10$ & $P<0.05$ \\
\hline MAP & $\mathrm{mmHg}$ & $76.9 \pm 12.8$ & $80.2 \pm 9.8$ & n.s. \\
\hline Pulse & bpm & $101 \pm 19$ & $101 \pm 20$ & n.s. \\
\hline \multicolumn{5}{|l|}{ Respiration } \\
\hline $\mathrm{PaO} 2$ & $\mathrm{kPa}$ & $13.0 \pm 3.1$ & $13.4 \pm 4.0$ & n.s. \\
\hline $\mathrm{FiO} 2$ & $\%$ & $40.8 \pm 19.4$ & $40.0 \pm 16.3$ & n.s. \\
\hline \multicolumn{5}{|l|}{ Coagulation } \\
\hline INR & & $1.29 \pm 0.25$ & $1.44 \pm 0.29$ & $P<0.01$ \\
\hline aPTT & $\mathrm{sec}$ & $53.8 \pm 50.2$ & $85.8 \pm 47.4$ & $P<0.05$ \\
\hline Antithrombin III & $\%$ & $65.6 \pm 16.8$ & $58.4 \pm 15.3$ & $P<0.01$ \\
\hline Fibrinogen & $g / l$ & $5.07 \pm 2.25$ & $4.62 \pm 2.15$ & $P<0.01$ \\
\hline D-Dimere & $\mu g / l$ & $752 \pm 505$ & $853 \pm 450$ & $P<0.05$ \\
\hline Platelets & Gpt/I & $163 \pm 130$ & $169 \pm 152$ & n.s. \\
\hline \multicolumn{5}{|l|}{ Other } \\
\hline Urea & $\mathrm{mmol} / \mathrm{l}$ & $13.5 \pm 7.5$ & $15.0 \pm 8.4$ & $P<0.01$ \\
\hline Creatinin & $\mu \mathrm{mol} / / \mathrm{l}$ & $129 \pm 99$ & $132 \pm 108$ & n.s. \\
\hline Bilirubin & $\mu \mathrm{mol} / \mathrm{l}$ & $33.1 \pm 44.2$ & $35.4 \pm 44.8$ & n.s. \\
\hline
\end{tabular}

MAP, Mean arterial pressure; INR, International normalized ratio; aPT, Activated partial thromboplastin time

$\pm 17 \%$ at the beginning to $58 \pm 15 \%$ at the end of the treatments, and improved slightly over the following 12 $\mathrm{h}$ to $61 \pm 15 \%$. Both activated partial thromboplastin time (aPTT) and prothrombin time (as International Normalized Ratio, INR) increased during the treatments due to heparin use but returned to pre-treatment values within $12 \mathrm{~h}$ after the extracorporeal circulation. No hemorrhages were observed.

\section{Hemolysis}

No signs of hemolysis were observed. Haptoglobin remained within the normal range and no significant change in lactate dehydrogenase was seen during the treatments.

Moreover, no allergic reactions were recognized.

Secondary endpoints (safety and efficacy): comparison of projected and observed mortality

Expected in-hospital mortality based on the ICU entrance APACHE II $(29.9 \pm 7.2)$ and SAPS II $(66.2 \pm$ $19.5)$ scores were $69.1 \%$ and $71.5 \%$, respectively [18-20]. The observed mortality rate was 3 out of 10 within 28 days (on days 6, 9, and 18), and four during hospital stay (Patient 7 died on Day 40). Six patients could be discharged from the hospital in stable condition. No significant differences were seen between the survivors and non-survivors in the time at ICU before inclusion or the time between inclusion and first treatment.

Organ functions, vital signs and laboratory parameters The body temperature of the patients was stable during the treatments (Table 2). While creatinine did not show a significant change during the six-hour treatments there were small but significant increases in urea (Table 2 ), most probably due to interruption of dialysis in patients with renal failure. However, urea decreased again slightly within $12 \mathrm{~h}$ post treatment to $14.7 \pm 8.4$ $\mathrm{mmol} / \mathrm{l}$. No difference in $\mathrm{PaO} 2$ and $\mathrm{FiO} 2$ has been observed between start and end of the extracorporeal treatment (Table 2). Furthermore, no significant changes have been seen in $\mathrm{PaO} 2$ or $\mathrm{FiO} 2$ between the treatment day and the day after the treatment.

\section{Inflammation}

During the six-hour treatment a dramatic increase in white blood cell (WBC) counts was observed (Table 2). 
This increase was not due to changes in a particular subset of WBC, the ratio of segmented to banded neutrophils remained unchanged. Furthermore, there was a significant decrease in plasma endotoxin concentration from pre- to post-treatment (Table 2). In 11 of the tested cytokines a significant increase pre vs. post cellbioreactor was observed (IL-2,-4,-8,-10,-1beta,-12, IP-10, Interferon gamma, Eotaxin, PDGF, RANTES). This resulted in significant increases pre- vs. post-treatment in the patients' plasma in 5 out of these 11 cytokines (IL-8,-10,-1beta, Eotaxin, RANTES) (Table 3). Moreover, there were significant decreases both in CRP as well as in PCT during the treatments (Table 2).

\section{Results of the 28-day observation period}

The statistical evaluation of the raw data showed improvements in several parameters evaluated during the 28 days of observation. The main findings include: significant reduction in CRP (Figure 3), PCT (Figure 4) and IL-8 (not shown); significant increase in HLA-DR on CD14-positive monocytes (Figure 5); significant increase in platelets and antithrombin III (not shown); significant reduction in noradrenaline use (Figure 6); significant reduction in alanine transaminase, aspartate transaminase and creatinine (not shown); and significant reduction in MODS and SOFA scores (not shown).

Out of these parameters PCT values, Noradrenaline dosage and SOFA score showed improvement already prior to the first treatment and further improved during the observation period.

In order to limit the bias due to the dropout of the non-survivors, an additional LOCF analysis was performed that also showed significant improvements for CRP, PCT, HLA-DR, noradrenaline, and creatinine.

Due to the large inter-individual differences no significant changes in leukocyte counts were seen except directly before and after treatment (see above).

Table 3 Changes in cytokine concentrations in patients' bood (left side) and in the extracorporeal circuit (right side)

\begin{tabular}{|c|c|c|c|c|c|c|c|c|}
\hline \multirow[b]{2}{*}{ Mediator } & \multicolumn{4}{|c|}{ Patient } & \multicolumn{4}{|c|}{ Extracorporeal circuit during treatment } \\
\hline & $\begin{array}{c}\text { Before extracorporeal } \\
\text { treatment }\end{array}$ & $\begin{array}{c}\text { After } 6 \mathrm{~h} \text { extracorporeal } \\
\text { treatment }\end{array}$ & $\%$ & $P$ & $\begin{array}{l}\text { Directly before cell } \\
\text { compartment }\end{array}$ & $\begin{array}{l}\text { Directly behind cell } \\
\text { compartment }\end{array}$ & $\%$ & $P$ \\
\hline IL-2 & 3.67 & 11.92 & 325 & n.s. & 0.78 & 1.42 & 182 & $<0.05$ \\
\hline $\mid \mathrm{L}-4$ & 0.87 & 2.29 & 263 & n.s. & 0.09 & 0.24 & 268 & $<0.001$ \\
\hline IL-6 & 102.22 & 313.15 & 306 & n.s. & 226.06 & 299.38 & 132 & n.s. \\
\hline $\mid \mathrm{L}-8$ & 20.39 & 41.31 & 203 & $<0.05$ & 31.79 & 165.15 & 520 & $<0.001$ \\
\hline IL-10 & 2.57 & 6.54 & 254 & $<0.01$ & 3.86 & 6.02 & 156 & $<0.05$ \\
\hline IL-1 beta & 1.21 & 2.12 & 175 & $<0.05$ & 0.74 & 1.11 & 150 & $<0.05$ \\
\hline IL-5 & 0.42 & 1.33 & 315 & n.s. & 0.39 & 0.52 & 135 & n.s. \\
\hline IL-7 & 3.19 & 5.19 & 163 & n.s. & 2.64 & 4.14 & 157 & n.s. \\
\hline IL-12(p70) & 2.46 & 9.65 & 392 & n.s. & 0.09 & 0.45 & 498 & $<0.001$ \\
\hline IL-13 & 1.68 & 3.34 & 199 & n.s. & 0.85 & 1.05 & 124 & n.s. \\
\hline IL-17 & 0.05 & 0.59 & 1185 & n.s. & 0.04 & 0.10 & 274 & n.s. \\
\hline IL-1ra & 106.96 & 208.03 & 194 & n.s. & 113.40 & 134.53 & 119 & n.s. \\
\hline IL-15 & 4.19 & 6.35 & 151 & n.s. & 3.20 & 4.37 & 136 & n.s. \\
\hline IL-9 & 1.11 & 8.15 & 737 & n.s. & 0.29 & 0.78 & 265 & n.s. \\
\hline IP-10 & 240.16 & 561.57 & 234 & n.s. & 508.51 & 749.08 & 147 & $<0.05$ \\
\hline G-CSF & 30.84 & 43.73 & 142 & n.s. & 50.87 & 53.44 & 105 & n.s. \\
\hline GM-CSF & 10.81 & 50.79 & 470 & n.s. & 1.52 & 3.41 & 224 & n.s. \\
\hline $\begin{array}{l}\text { IFN } \\
\text { gamma }\end{array}$ & 50.29 & 79.07 & 157 & n.s. & 14.83 & 25.26 & 170 & $<0.05$ \\
\hline TNF alpha & 0.00 & 0.00 & 100 & n.s. & 0.81 & 0.19 & 24 & n.s. \\
\hline $\begin{array}{l}\text { MCP-1 } \\
\text { (MCAF) }\end{array}$ & 130.72 & 224.46 & 172 & n.s. & 299.52 & 225.67 & 75 & n.s. \\
\hline MIP-1b & 55.93 & 98.89 & 177 & n.s. & 76.92 & 103.23 & 134 & n.s. \\
\hline Eotaxin & 85.64 & 216.82 & 253 & $<0.05$ & 80.23 & 130.72 & 163 & $<0.01$ \\
\hline FGF basic & 1.51 & 9.47 & 629 & n.s. & 0.61 & 0.00 & 0 & n.s. \\
\hline PDGF bb & 652.01 & 1145.02 & 176 & n.s. & 10.28 & 62.25 & 606 & $<0.001$ \\
\hline RANTES & 137.70 & 298.64 & 217 & $<0.05$ & 22.91 & 141.43 & 617 & $<0.001$ \\
\hline VEGF & 168.92 & 198.68 & 118 & n.s. & 1.12 & 2.45 & 219 & n.s. \\
\hline $\begin{array}{l}\text { MIP-1 } \\
\text { alpha }\end{array}$ & 0.39 & 1.00 & 253 & n.s. & 0.34 & 0.51 & 148 & n.s. \\
\hline
\end{tabular}




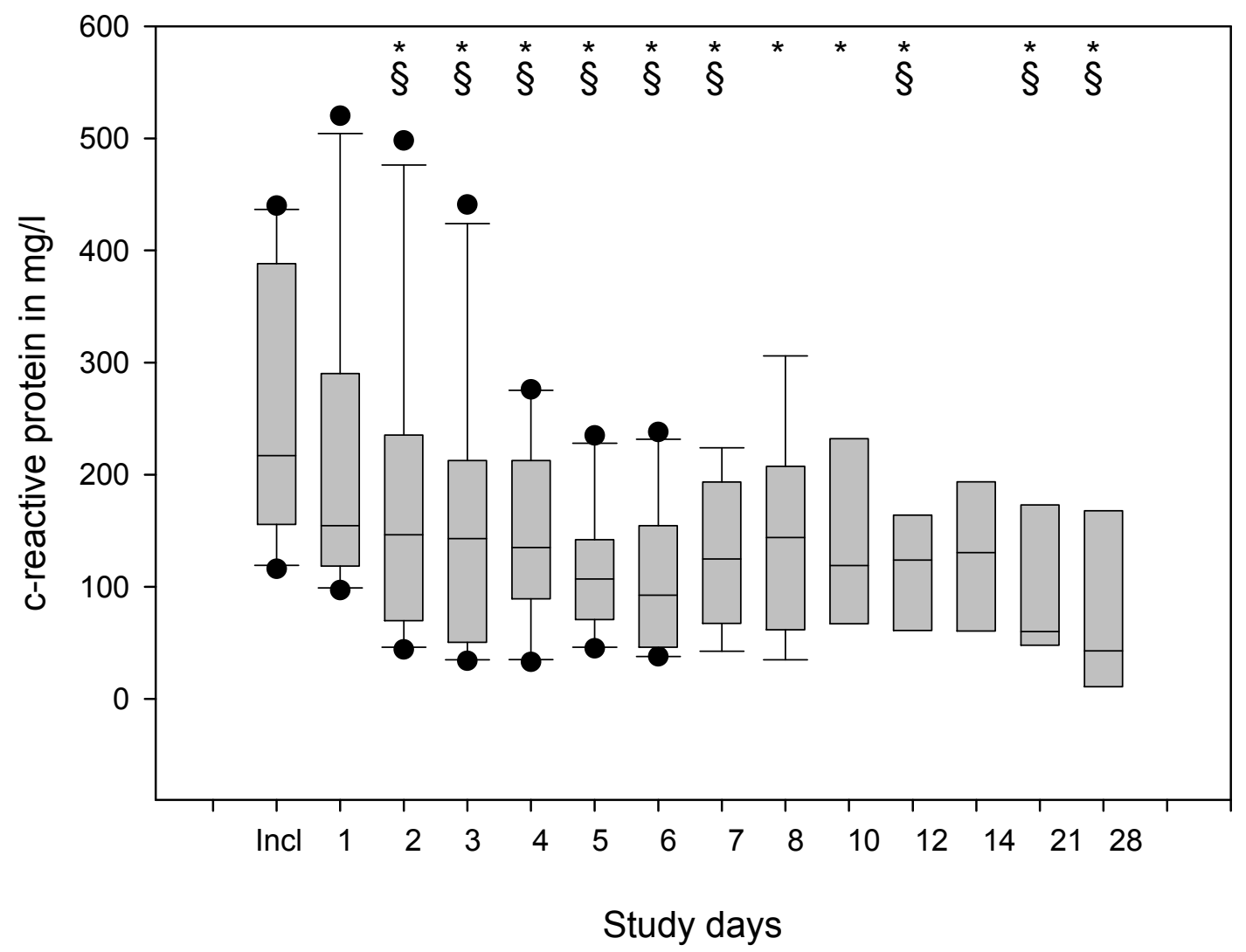

Figure 3 Box plots of data describing the time course of C-reactive protein. Significant changes $(P<0.05)$ vs. inclusion day (indicated by *) and vs. Day 1 (§) were observed.

\section{Discussion}

Today's best treatment of sepsis includes early and aggressive antibiotic therapy and effective support for failing organ systems including metabolic stability and maintenance of stable hemodynamic [21]. Immunomodulation has been introduced as an adjunctive therapeutic approach to overcome immune system dysfunction and could show positive impact on survival in some studies [22] but failed in a number of other studies [23,24]. Extracorporeal blood detoxification methods have also been suggested to successfully influence immune imbalances and subsequently clinical course and outcome of multi-organ failure and sepsis [25]. High volume hemofiltration [26], high cut-off hemofiltration [27], high adsorption hemofiltration [28]; coupled plasma filtration adsorption (CPFA) [29]; plasma- or whole blood perfusion through adsorptive columns [30]; and plasma or whole blood exchange have been proposed (for review see $[31,32])$. Cytokines, for example, can be significantly reduced in the circulation of septic patients by extracorporeal treatments. Techniques capable of removing larger molecules/particles from plasma (that is, highvolume treatments, large-pore filtration, plasmapheresis and adsorption) appear to have a stronger impact on clinical course and outcome than techniques primarily addressing smaller water-soluble molecules $[29,33]$.

Extracorporeal bioreactors were studied in the treatment of various diseases. Acute liver failure [34] and acute renal failure associated with sepsis [35] have been targeted by different cell-based extracorporeal organ support systems using hepatocytes or renal tubular cells. Proper choice of the cell-source turned out to be of central importance [36]. However, the use of immune cells to treat sepsis in an extracorporeal setting has not been reported so far.

Allogeneic blood transfusions have been implicated to increase the risk of nosocomial infections and are independently associated with increased length of stay and mortality in critically ill patients [37]. Leukocytes are thought to trigger this effect and leuko-reduction of blood transfusions was found to result in a decrease of infections and mortality in post-operative intensive care [38]. Therefore, the intravenous transfusion of leukocytes remains under controversial discussion.

In a pig study of Staphylococcus aureus-induced sepsis, the extracorporeal granulocyte-treatment resulted in 


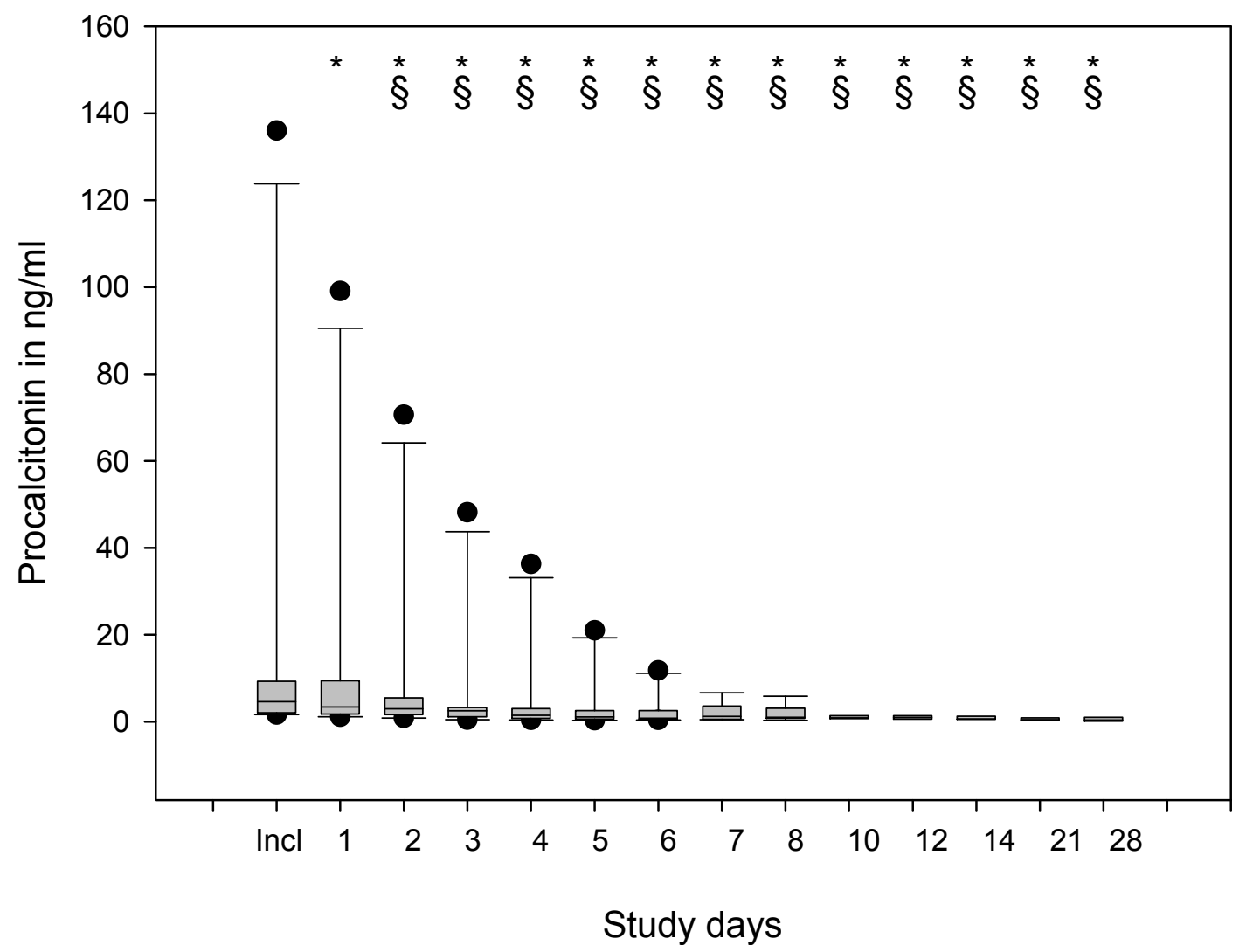

Figure 4 Box plots of data describing the time course of procalcitonin. Significant changes $(P<0.05)$ vs. inclusion day (indicated by *) and vs. Day 1 (§) were observed.

significant improvement of one-week survival as compared to both the untreated and the sham control. The effect on survival was dependent on the presence of granulocytic HL-60 cells in the bioreactor device. In the sham-bioreactor-treated group no survival benefit was observed [15].

In this current study 10 patients with septic shock were treated. The plasma of the patients had a strong inhibitory effect on the functionality (that is, oxyburst) of myeloid cell lines, indicating a neutrophil functioninhibiting milieu in all patients (data not shown). This is in line with reports in the literature [7].

The extracorporeal cell-treatment was well tolerated both with regard to technical safety of the procedure as well as the biocompatibility of the allogeneic bioreactorcells. No adverse effects were noted that could be accounted for by the presence of the human phagocytic cells. Specifically, no unwanted effects were observed in the function of the lungs or other organs as were reported following GTx-treatments.

The dosage of anticoagulation needed to be increased following an episode of clotting observed during the first single treatment. For all following treatments a higher target ACT was adopted. After the adaptation, no clotting or increased bleeding episodes were observed.

The hemodynamic situation of the patients improved significantly through the course of the treatment. This is a remarkable finding as other extracorporeal blood treatments such as renal replacement therapies can induce hypotension and other unwanted effects in critically ill patients [39]. There is a correlation between vasopressor load and mortality in septic shock patients [40]. Thus, reduction of vasopressor load might be a valuable parameter for future clinical studies with the bioreactor device.

The increase in leukocyte count after six hours of treatment is one of the results that appear to be a direct effect of the bioreactor perfusion. It most likely is the consequence of a cytokine influx from the bioreactor. However, no clinically unwanted effect of this leukocytosis was observed, neither directly following treatment nor in the following days (that is, no organ dysfunction, especially no notable lung injury). This might be due to the "balanced" cytokine influx with both pro- and antiinflammatory cytokines (compare Table 3).

The 28-day results indicate stabilization of conditions in seven patients including normalization of the 


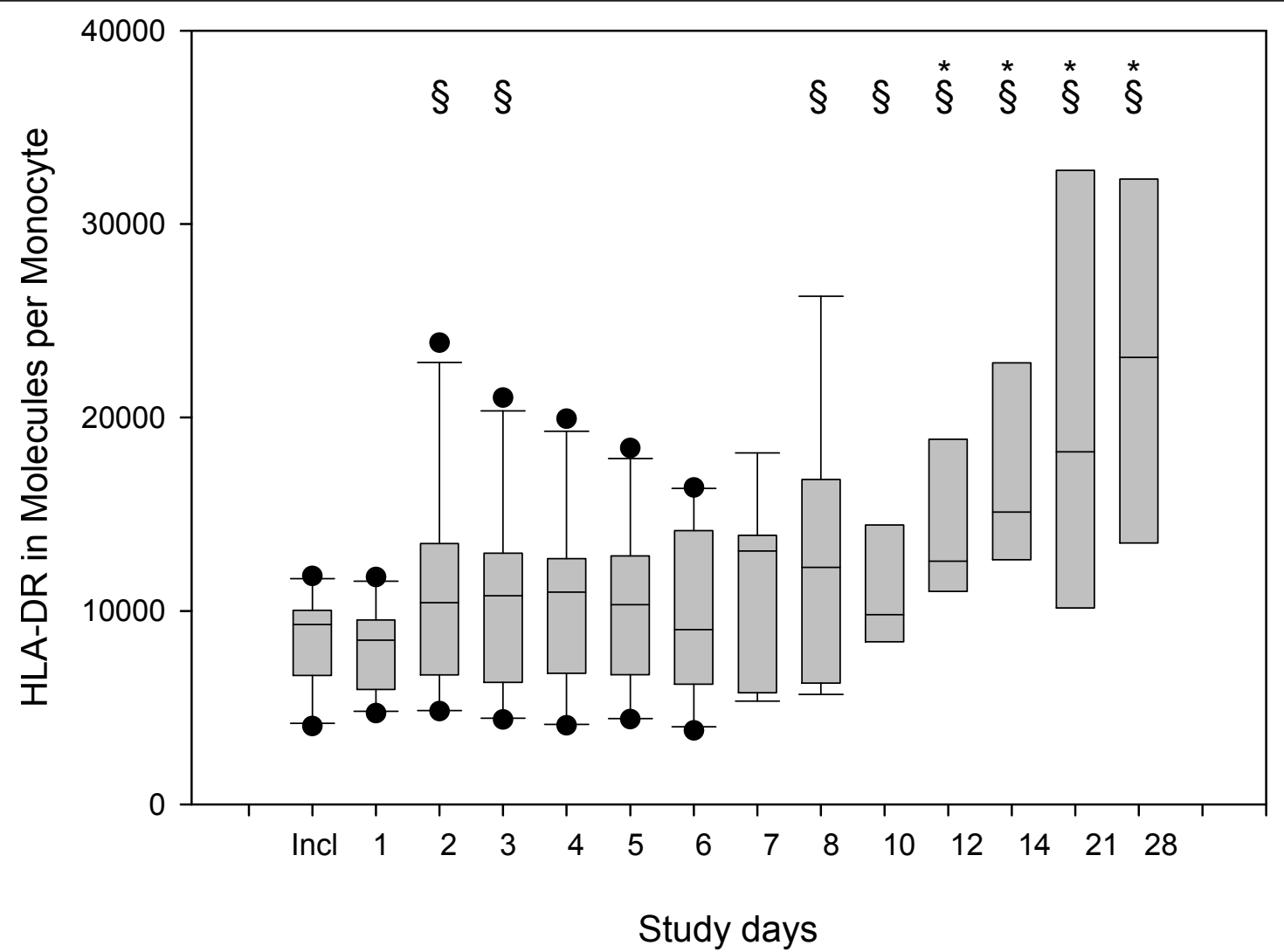

Figure 5 Box plots of data describing the time course of HLA-DR expression on CD14 positive monocytes. Significant changes $(P<0.05)$ vs. inclusion day (indicated by *) and vs. Day 1 (§) were observed.

inflammatory situation and reversal of organ failure, resulting in seven 28-day survivors and six hospital survivors. However, no conclusions about survival can be drawn based on this uncontrolled pilot study. Moreover, the favorable clinical course of the majority of patients cannot be linked only to the bioreactor treatments based on the present data. They might just reflect the natural course of the disease and the impact of proper standard intensive care treatment. Future clinical investigations will be needed to address these questions.

The mechanism of action of the device remains incompletely understood at present. The efficient removal of live bacteria by granulocytes was both proven in vitro and in the pig-bacteremia model $[14,15]$. There is already good evidence for removal of bacterial endotoxins as well as interaction on the mediator and cytokine level during this clinical study. This is in line with observations from the pig model [15]. Interestingly, the bioreactor cells released a mixture of pro-inflammatory as well as anti-inflammatory cytokines. The interactions on the cellular and mediator level will be another task to study in future clinical trials.

The present study has several limitations. As an uncontrolled pilot study it does not carry the capacity to answer any questions regarding clinical course or outcome of the patients. Further controlled studies in larger patient cohorts will need to address these questions. Although no severe unwanted effects were observed during the treatments, no final conclusion on the safety can be drawn based on the results from 20 single treatments in 10 patients. The course of biomarkers of inflammation and cytokines needs further investigation as well. The apparent link between fall in CRP and PCT following the bioreactor treatments needs to be separated from the effects induced by standard intensive care including application of antibiotics. The mechanism of cytokine response of the bioreactor needs further elucidation. The observed influx of pro- and anti-inflammatory cytokines into the patient surely is one of the most interesting results of this study. However, it has to be carefully followed in further investigations and its impact on patient's safety should be monitored closely.

At present extracorporeal detoxification methods already play an important role in intensive care therapy of septic multi organ failure, for example, as renal and liver dialysis [41]. A combination of various extracorporeal support approaches appears as an interesting option for future organ support strategies. 


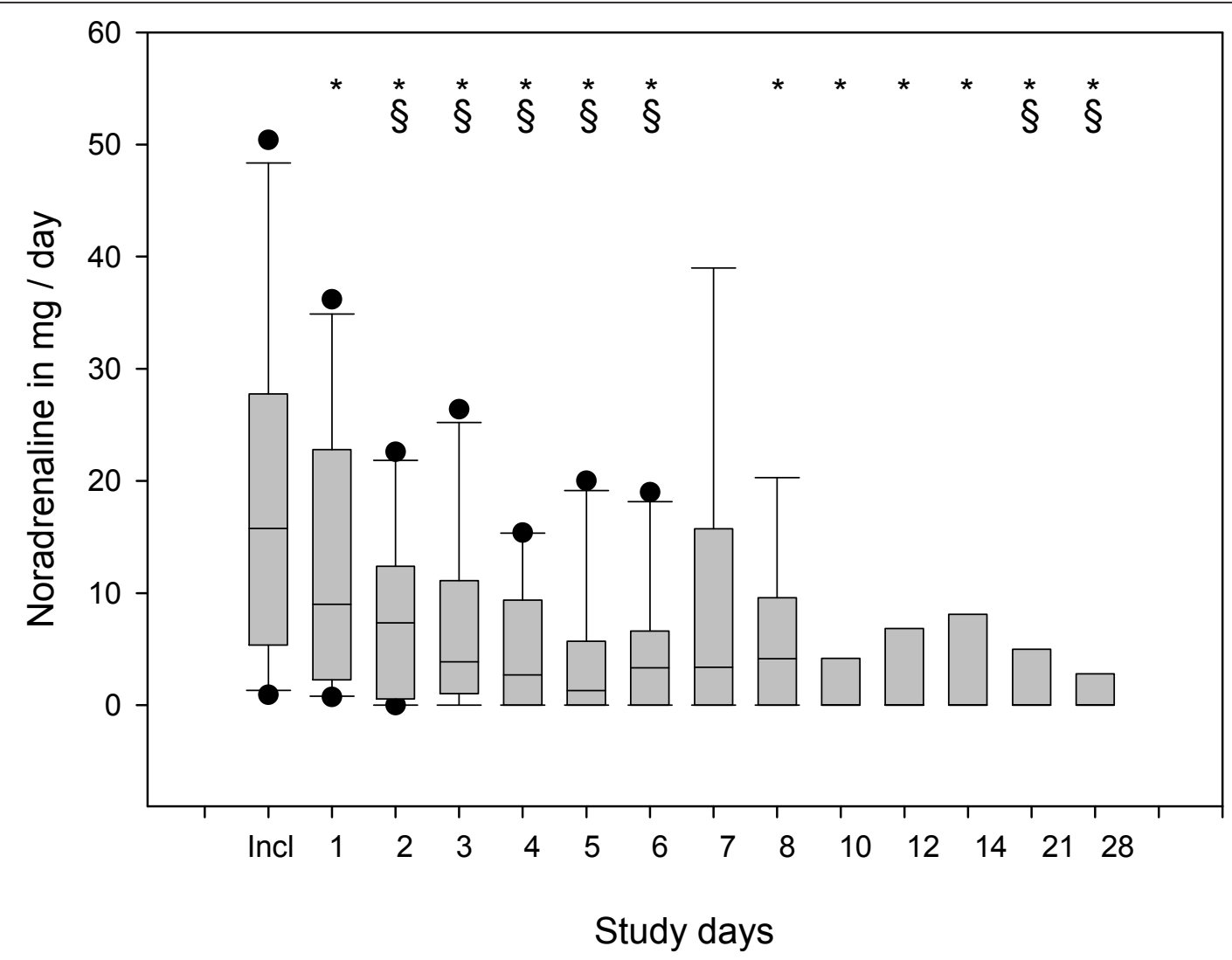

Figure 6 Box plots of data describing the time course of total daily noradrenaline dosage. Significant changes $(P<0.05)$ vs. inclusion day (indicated by *) and vs. Day 1 (§) were observed.

\section{Conclusions}

The objective of the current study was to deploy donor granulocytes in patients with septic shock and immune cell-paralysis in a strictly extracorporeal setting and, thereby, prevent potential local side effects in the inflamed tissue.

In summary, the results of the present study mainly indicate three things: a) extracorporeal plasma-treatment with granulocytic cells is well tolerated in critically ill patients with septic shock, b) treatment was associated with significant improvement of the hemodynamic situation of the patients, and c) clinical courses of the patients in this pilot study encourage further clinical studies with this therapeutic approach.

\section{Key messages}

- A bedside-bioreactor with donor granulocytes was clinically tested in 10 patients with septic shock.

- Every patient was treated twice for six hours each. The treatments were tolerated well by the patients.

- The bioreactor cells released a mix of pro- and anti-inflammatory cytokines that had an impact on the cytokine levels in the patient.
- Parameters describing immune cell function (HLADR), inflammation status (CRP, PCT, WBC), hemodynamics (vasopressor dosage) of the patients improved during the treatment.

- Labchemical and clinical results encourage further clinical studies.

\section{Abbreviations}

ACT: activated clotting time; APACHE: Acute Physiology and Chronic Health Evaluation (Score); aPTT: activated partial thromboplastin time; CPFA: coupled plasma filtration adsorption; CRP: C-reactive protein; FGF: fibroblast growth factor; G-CSF: granulocyte-colony stimulating factor; GM-CSF: granulocyte-macrophage-colony stimulating factor; GTx: granulocyte transfusion; HLA-DR: human leukocyte antigen DR; IFN: interferon; IL: interleukin; INR: International Normalized Ratio; LOCF: Last Observation Carried Forward; MCP-1: monocyte chemotactic protein-1; MIP-1: macrophage inflammatory protein 1; MODS: Multiple Organ Dysfunction Score; PCT: procalcitonin; PDGF: platelet-derived growth factor; SAPS: Simplified Acute Physiology Score; SD: Standard Deviation; SOFA: Sequential Organ Failure Assessment (Score); SPSS: Statistical Package for the Social

Sciences; SVRI: systemic vascular resistance index; TNF: tumor necrosis factor; VEGF: vascular endothelial growth factor.

\section{Acknowledgements}

The authors want to thank Matthias Suraj for his valuable technical support, Volker Kiefel for his support in the delivery of the granulocyte donations as well as Martin Scholz for his critical review of the manuscript. 


\section{Author details}

'Department of Medicine, Division of Nephrology, Medical Faculty of the University of Rostock, Ernst-Heydemann-Str. 6, Rostock, D-18057, Germany. ${ }^{2}$ Department of Anesthesiology and Intensive Care Medicine, Medical Faculty of the University of Rostock, Schillingallee 35, Rostock, D-18057, Germany. ${ }^{3}$ Department of Medicine, Division of Transfusion Medicine, Medical Faculty of the University of Rostock, Ernst-Heydemann-Str. 6, Rostock, D-18057, Germany. ${ }^{4}$ Department of Medicine, Intensive Care Unit, Medical Faculty of the University of Rostock, Ernst-Heydemann-Str. 6, Rostock, D-18057, Germany. ${ }^{5}$ Department of Surgery, Medical Faculty of the University of Rostock, Schillingallee 35, Rostock, D-18057, Germany.

\section{Authors' contributions}

JA did the regulatory work and coordinated the preparation of the manuscript. JA and KK did the data analysis. MS, SRM, HH, SK, TB, DV, GNS, $M G, J H, A P$ and EK were clinical investigators of the study and performed the treatments. DG did the donor screening and the donor granulocyte collections. All authors participated in the design of the study, and read and approved the final manuscript.

\section{Competing interests}

JA and SRM have filed patents on the technology of extracorporeal cell perfusion technology, own shares of and work part-time as consultants for Artcline $\mathrm{GmbH}$, a University spin-off that now owns the patent rights. MS works part-time as a consultant for Artcline $\mathrm{GmbH}$. Artcline will pay the article processing charge of this journal. KK, HH, SK, TB, DV, GNS, MG, JH, AP, EK and DG declare that they have no competing interests.

Received: 17 October 2010 Revised: 14 January 2011

Accepted: 3 March 2011 Published: 3 March 2011

\section{References}

1. Angus DC, Linde-Zwirble WT, Lidicker J, Clermont G, Carcillo J, Pinsky MR: Epidemiology of severe sepsis in the United States: analysis of incidence, outcome, and associated costs of care. Crit Care Med 2001, 29:1303-1310.

2. Karzai W, Cui X, Heinicke N, Niemann C, Gerstenberger EP, Correa R, Banks S, Mehlhorn B, Bloos F, Reinhart K, Eichacker : Neutrophil stimulation with granulocyte colony-stimulating factor worsens ventilator-induced lung injury and mortality in rats. Anesthesiology 2005, 103:996-1005.

3. Hoesel LM, Neff TA, Neff SB, Younger JG, Olle EW, Gao H, Pianko MJ, Bernacki KD, Sarma JV, Ward PA: Harmful and protective roles of neutrophils in sepsis. Shock 2005, 24:40-47.

4. Scholz M, Cinatl J, Schädel-Höpfner M, Windolf J: Neutrophils and the blood-brain barrier dysfunction after trauma. Med Res Rev 2007, 27:401-416.

5. Alves-Filho JC, de Freitas A, Spiller F, Souto FO, Cunha FQ: The role of neutrophils in severe sepsis. Shock 2008, 30:3-9.

6. Caille V, Chiche JD, Nciri N, Berton C, Gibot S, Boval B, Payen D, Mira JP, Mebazaa A: Histocompatibility leukocyte antigen-D related expression is specifically altered and predicts mortality in septic shock but not in other causes of shock. Shock 2004, 22:521-526.

7. Kaufmann I, Hoelzl A, Schliephake F, Hummel T, Chouker A, Peter K, Thiel M: Polymorphonuclear leukocyte dysfunction syndrome in patients with increasing sepsis severity. Shock 2006, 26:254-261.

8. Carr R, Modi N, Dore C: G-CSF and GM-CSF for treating or preventing neonatal infections. Cochrane Database Syst Rev 2003, CD003066.

9. Napolitano LM: Immune stimulation in sepsis: to be or not to be? Chest 2005, 127:1882-1885.

10. Murphey ED, Sherwood ER: Bacterial clearance and mortality are not improved by a combination of IL-10 neutralization and IFN-gamma administration in a murine model of post-CLP immunosuppression. Shock 2006, 26:417-424.

11. Mohan P, Brocklehurst P: Granulocyte transfusions for neonates with confirmed or suspected sepsis and neutropaenia. Cochrane Database Syst Rev 2003, CD003956.

12. Stanworth SJ, Massey E, Hyde C, Brunskill S, Lucas G, Navarrete C, Marks DI: Granulocyte transfusions for treating infections in patients with neutropenia or neutrophil dysfunction. Cochrane Database Syst Rev 2005, CD005339.
13. Safdar A, Hanna HA, Boktour M, Kontoyiannis DP, Hachem R, Lichtiger B, Freireich EJ, Raad II: Impact of high-dose granulocyte transfusions in patients with cancer with candidemia: retrospective case-control analysis of 491 episodes of Candida species bloodstream infections. Cancer 2004, 101:2859-2865.

14. Mitzner SR, Freytag J, Sauer M, Kleinfeldt T, Altrichter J, Klöhr S, Koball S, Stange J, Ringel B, Nebe B, Schmidt H, Podbielski A, Noeldge-Schomburg G, Schmidt R: Use of human preconditioned phagocytes for extracorporeal immune support: introduction of a concept. Ther Apher 2001, 5:423-432.

15. Sauer M, Altrichter A, Kreutzer HJ, Lögters T, Scholz M, NöldgeSchomburg G, Schmidt R, Mitzner SR: Extracorporeal cell therapy with granulocytes in a pig-model of Gram-positive sepsis. Crit Care Med 2009, 37:606-613.

16. American College of Chest Physicians/Society of Critical Care Medicine Consensus Conference: Definitions for sepsis and organ failure and guidelines for the use of innovative therapies in sepsis. Crit Care Med 1992, 20:864-874.

17. Bernard GR, Vincent JL, Laterre PF, LaRosa SP, Dhainaut JF, LopezRodriguez A, Steingrub JS, Garber GE, Helterbrand JD, Ely EW, Fisher CJ Jr: Efficacy and safety of recombinant human activated protein $\mathrm{C}$ for severe sepsis. N Engl J Med 2001, 344:699-709.

18. Knaus WA, Draper EA, Wagner DP, Zimmerman JE: APACHE II: a severity of disease classification system. Crit Care Med 1985, 13:818-829.

19. Lemeshow S, Le Gall JR: Modeling the severity of illness of ICU patients. A systems update. JAMA 1994, 272:1049-1055.

20. Le Gall JR, Lemeshow S, Saulnier F: A new Simplified Acute Physiology Score (SAPS II) based on a European/North American multicenter study. JAMA 1993, 270:2957-2963, (Erratum in: JAMA 1994, 271:1321).

21. Dellinger RP, Levy MM, Carlet JM, Bion J, Parker MM, Jaeschke R, Reinhart $K$ Angus DC, Brun-Buisson C, Beale R, Calandra T, Dhainaut JF, Gerlach H, Harvey M, Marini JJ, Marshall J, Ranieri M, Ramsay G, Sevransky J, Thompson BT, Townsend S, Vender JS, Zimmerman JL, Vincent JL: Surviving Sepsis Campaign: international guidelines for management of severe sepsis and septic shock. Intensive Care Med 2008, 34:17-60.

22. Kreymann $\mathrm{KG}$, de Heer $\mathrm{G}$, Nierhaus A, Kluge $\mathrm{S}$ : Use of polyclonal immunoglobulins as adjunctive therapy for sepsis or septic shock. Crit Care Med 2007, 35:2677-2685.

23. Bochud PY, Calandra T: Pathogenesis of sepsis: new concepts and implications for future treatment. BMJ 2003, 326:262-266.

24. Nasraway SA: The problems and challenges of immunotherapy in sepsis. Chest 2003, 123:451S-459S.

25. Ronco C, Inguaggiato P, D'Intini V, Cole L, Bellomo R, Poulin S, Bordoni V, Crepaldi C, Gastaldon F, Brendolan A, Trairak P, Khajohn T: The role of extracorporeal therapies in sepsis. J Nephrol 2003, 16:S34-S41.

26. Honore PM, Joannes-Boyau O, Boer W, Collin V: High-volume hemofiltration in sepsis and SIRS: current concepts and future prospects. Blood Purif 2009, 28:1-11.

27. Morgera S, Haase M, Kuss T, Vargas-Hein O, Zuckermann-Becker H, Melzer C, Krieg H, Wegner B, Bellomo R, Neumayer HH: Pilot study on the effects of high cutoff hemofiltration on the need for norepinephrine in septic patients with acute renal failure. Crit Care Med 2006, 34:2099-2104

28. Rimmelé $T$, Assadi A, Cattenoz M, Desebbe O, Lambert C, Boselli E, Goudable J, Etienne J, Chassard D, Bricca G, Allaouchiche B: High-volume haemofiltration with a new haemofiltration membrane having enhanced adsorption properties in septic pigs. Nephrol Dial Transplant 2009, 24:421-427.

29. Ronco C, Brendolan A, Lonnemann G, Bellomo R, Piccinni P, Digito A Dan M, Irone M, La Greca G, Inguaggiato P, Maggiore U, De Nitti C, Wratten ML, Ricci Z, Tetta C: A pilot study of coupled plasma filtration with adsorption in septic shock. Crit Care Med 2002, 30:1250-1255.

30. Kellum JA, Song M, Venkataraman R: Hemoadsorption removes tumor necrosis factor, interleukin-6, and interleukin-10, reduces nuclear factorkappaB DNA binding, and improves short-term survival in lethal endotoxemia. Crit Care Med 2004, 32:801-805.

31. Bellomo R, Honoré PM, Matson J, Ronco C, Winchester J: Extracorporeal blood treatment (EBT) methods in SIRS/Sepsis. Int J Artif Organs 2005, 28:450-458.

32. Peng Z, Singbartl K, Simon P, Rimmelé T, Bishop J, Clermont G, Kellum JA: Blood purification in sepsis: a new paradigm. Contrib Nephrol 2010, 165:322-328. 
33. Busund R, Koukline V, Utrobin U, Nedashkovsky E: Plasmapheresis in severe sepsis and septic shock: a prospective, randomised, controlled trial. Intensive Care Med 2002, 28:1434-1439.

34. Demetriou AA, Brown RS Jr, Busuttil RW, Fair J, McGuire BM, Rosenthal P, Am Esch JS, Lerut J, Nyberg SL, Salizzoni M, Fagan EA, de Hemptinne B, Broelsch CE, Muraca M, Salmeron JM, Rabkin JM, Metselaar HJ, Pratt D, De La Mata M, McChesney LP, Everson GT, Lavin PT, Stevens AC, Pitkin Z, Solomon BA: Prospective, randomized, multicenter, controlled trial of a bioartificial liver in treating acute liver failure. Ann Surg 2004, 239:660-667.

35. Tumlin J, Wali R, Williams W, Murray P, Tolwani AJ, Vinnikova AK, Szerlip HM, Ye J, Paganini EP, Dworkin L, Finkel KW, Kraus MA, Humes HD: Efficacy and safety of renal tubule cell therapy for acute renal failure. $J$ Am Soc Nephrol 2008, 19:1034-1040.

36. Stange J, Mitzner S: Cell sources for bioartificial liver support. Int J Artif Organs 1996, 19:14-17.

37. Taylor RW, O'Brien J, Trottier SJ, Manganaro L, Cytron M, Lesko MF, Arnzen K, Cappadoro C, Fu M, Plisco MS, Sadaka FG, Veremakis C: Red blood cell transfusions and nosocomial infections in critically ill patients. Crit Care Med 2006, 34:2302-2308.

38. Blajchman MA: The clinical benefits of the leukoreduction of blood products. J Traum 2006, 60:583-590.

39. Uchino S, Bellomo R, Morimatsu H, Morgera S, Schetz M, Tan I, Bouman C, Macedo E, Gibney N, Tolwani A, Oudemans-van Straaten H, Ronco C, Kellum JA: Continuous renal replacement therapy: a worldwide practice survey. The beginning and ending supportive therapy for the kidney (B. E.S.T. kidney) investigators. Intensive Care Med 2007, 33:1563-1570.

40. Dünser MW, Ruokonen E, Pettilä V, Ulmer H, Torgersen C, Schmittinger CA, Jakob S, Takala J: Association of arterial blood pressure and vasopressor load with septic shock mortality: a post hoc analysis of a multicenter trial. Crit Care 2009, 13:R181.

41. Mitzner S, Klammt S, Stange J, Schmidt R: Albumin regeneration in liver support - comparison of different methods. Therapeutic Apheresis and Dialysis 2006, 10:108-117.

\section{doi:10.1186/cc10076}

Cite this article as: Altrichter et al.: Extracorporeal cell therapy of septic shock patients with donor granulocytes: a pilot study. Critical Care 2011 15:R82.

\section{Submit your next manuscript to BioMed Central and take full advantage of:}

- Convenient online submission

- Thorough peer review

- No space constraints or color figure charges

- Immediate publication on acceptance

- Inclusion in PubMed, CAS, Scopus and Google Scholar

- Research which is freely available for redistribution 